\title{
PAPER
}

\section{Is human society in denial regarding the tough questions about sustainability?}

\author{
John Cairns, Jr.* \\ Department of Biology, Virginia Polytechnic Institute and State University, Blacksburg, Virginia 24061, USA
}

\begin{abstract}
The news media report daily on unsustainable practices and events that impede progress toward sustainable use of the planet - production of greenhouse gases, biotic impoverishment, depletion of fossil waters (aquifers), human population growth, production of persistent toxic substances, loss of agricultural topsoil and land, rapid loss of old growth forests, and so on. Exponential economic growth both depletes natural capital more rapidly than it is regenerated and also gives an illusion of sustainable prosperity. Failure to act more expeditiously is almost certainly due to a number of factors; however, denial that a problem exists is, arguably, one of the most likely reasons. Just as an alcoholic or drug addict must first acknowledge that a problem exists before successful treatment is possible, so must those addicted to exponential growth on a finite planet.
\end{abstract}

KEY WORDS: Denial $\cdot$ Sustainability $\cdot$ Resource allocation $\cdot$ Depletion of natural capital $\cdot$ Memes Eco-ethics

Resale or republication not permitted without written consent of the publisher

Facts do not cease to exist just because they are ignored.

Aldous Huxley

The growth ideology is extremely attractive politically because it offers a solution to poverty without requiring the moral disciplines of sharing and population control.

Herman Daly

I was first exposed to the dysfunctional relationship between human society and natural systems when Ruth Patrick became my mentor in 1948. Her goal was 'use without abuse' of natural systems. At that time, public awareness of environmental pollution was just beginning to increase. Leopold's (1949) Sand County Almanac provided a superb description of how natural systems functioned. Then, Carson's (1962) Silent Spring alerted me to the probable ecological damage of pesticides and also showed the intensity of the attacks likely to occur if the status quo were challenged. Next came Hardin's (1968) classic 'Tragedy of the Commons' and subsequent publications using the metaphors of lifeboats (Hardin 1974) and spaceships (Hardin 1972) to illustrate carrying capacity (Hardin 1976). Of course, there were many others, but these caused a major paradigm shift early in my career.
Mainstream science became much more interested in environmental science and studies, as evidenced by the first Earth Day in 1971. However, humankind still persisted in denying the extent of the problem. Denial is not new. Pliny the Elder stated, in the first century, that the stupid ostrich thrusts its head and neck into a bush and imagines that the entire body is concealed (Hardin 1999).

Other authors have espoused a no-need-for-concern attitude - everything is fine. Simon (1981) believed in unlimited growth. Naturally, this idea has critics (e.g. Daly 2003). Recently, Lomborg (2001) has created quite a stir, especially in the financial news (positive) (e.g. Cambridge University Press ${ }^{1}$ ) and the academic journals ${ }^{1}$ See the 2004 review available online at http://uk.cambridge.
org/economics/lomborg/reviews.htm 
(negative) (e.g. Union of Concerned Scientists ${ }^{2}$ ). The Editors (Editorial 1997) of Scientific American have described some of this debate as science vs. antiscience.

Another form of denial may be the possibility of the deliberate production of disinformation so that science does not contradict political, religious, or corporate ideologies. In the 1930s, the USSR denigrated mainstream genetics in favor of a fraudulent theory of heredity, which was congruent with Communist ideology $^{3}$ (Sheehan 1993). A statement condemning misuse of science was signed by 62 leading scientists, including 20 Nobel laureates and 19 recipients of the National Medal of Science. ${ }^{4}$ Time for resolving these issues is short. A very important factor is the $50-100$ years available for humankind to achieve sustainability with an estimated population of 8-11 billion (Palmer et al. 2004).

Although there is cause for concern, cautious optimism is also justified. For example, Brown (2003) has produced a plan at the planetary level that including restructuring the economy, stabilizing population, and stabilizing climate. At subcomponent levels, the outlook is also positive: (1) studies on renewable energy (Odum \& Odum 2001), (2) calls for behavior change (Green Week events ${ }^{5}$ ), (3) detailed studies of a hydrogen economy on the stratosphere, which will reduce uncertainty (Tromp et al. 2003), (4) plans for global climate monitoring are being discussed by scientists, although no robust plan has emerged so far, and (5) plans for preserving both land and the economy. ${ }^{6}$

An illustrative small town issue is ongoing in Blacksburg, Virginia, USA; a situation exists that is, in many ways, a microcosm of world environmental problems. The town has purchased a 169-acre, abandoned farm that shows exemplary ecosystem recovery (12 different habitats). One decision that must be made is whether this tract should be preserved as a nature park or turned into another mixed-use park (Browder et al. 2000). At a two-day workshop attended by about 500 residents, $80 \%$ of the citizens preferred that the land be used for nature preservation, environmental education, and passive recreation. Opponents favor an active-use plan (soccer fields, large parking lots for

${ }^{2}$ See 'UCS examines the "Skeptical Environmentalist"' by Bjorn Lomborg, 2003, available online at www.ucsusa.org/ global_environment/archive/page.cfm?pageID=533

${ }^{3}$ See the 2004 editorial 'Bush-league Lysenkoism: the White House bends science to its will'. Sci Am 26 Apr. Available online at www.sciam.com/article.cfm?articleID=0001E02AA14A-1084-983483414B7F0000\&ref=sciam\&chanID=sa004

${ }^{4}$ See 'Restoring Scientific Integrity in Policy Making', PDF download at www.ucsusa.org/news/press_release.cfm?newsID=385

${ }^{5}$ For details, visit www.urbangreendays.org/index.php?id=1059 ${ }^{6} \mathrm{See}$ 'A deal is reached to preserve land and the economy in the Adirondacks', A de Palma, 22 April 2004, available online at www.nynjtc.org/externalnews/2004/adk1.html spectators, etc.) in which the concept of a nature park does not emerge as a guiding principle, i.e. protection and observation of wildlife, environmental education, and contemplation of nature are not primary goals. In addition, citizens have rejected a 'master plan' by a 3 to 1 margin that calls for mixing a nature park and active-use elements. This impasse is occurring in a town where educational levels are above average and the democratic process is continually praised. Is there a discontinuity between citizens and elected officials? Do most citizens favor a nature park in principle but not in practice? Is a mixed-use compromise likely to maintain any significant remnants of the present biological diversity? Another intriguing possibility may be at work: human society is in denial about certain aspects of the human condition.

\section{THE CASE FOR DENIAL}

The word denial is defined as 'an assertion that something said, believed, alleged, etc. is false' or 'disbelief in the existence or in the reality of a thing. ${ }^{.7}$ Another definition is 'refusal to admit the truth or reality (as of a statement or charge), assertion that an allegation is false, negation in logic, a psychological defense mechanism in which confrontation with a personal problem or with reality is avoided by denying the existence of the problem or reality'. ${ }^{8}$ Kuhn (1970) defined a paradigm as a belief so strongly held that, even when contrary evidence appears, the evidence is rejected. Dobzhansky (1945) stated that no evidence is powerful enough to force acceptance of a conclusion that is emotionally distasteful. The following few illustrative examples show that problems with denial do exist.

1. Cigarette smoking does not cause cancer or other adverse health effects.

2. Global warming is a myth not based on scientific evidence.

3. Biotic impoverishment (species extinction) will not affect human society.

4. Every environmental problem has a technological solution.

5. The human population can keep expanding indefinitely.

6. Resources are not limiting.

By denying that environmental problems exist, most people avoid considering precautionary measures until the adverse consequences are horrendous. Human society is facing an unprecedented environmental crisis on a global scale. However, the aggregate

${ }^{7}$ From the Random House Dictionary, 2nd edn

${ }^{8}$ From Merriam-Webster's Collegiate Dictionary, 10th edn 
response to any evidence of a global crisis has been trivial, despite some heartening but uncommon case histories.

\section{PERCEPTION OF RISK}

World Watch magazine includes in each issue a page entitled 'Matters of Scale'. The Jan/Feb 2002 issue discusses 'Future of Risk', which is reproduced here. ${ }^{9}$

Number of people in Washington, D.C. who were murdered by anthrax poisoning between September 11 and November 9

Number of people murdered by other means in the same city during the same period

Number of U.S. residents who died of anthrax between October 1 and November 1

Approximate number of U.S. residents who died, during the same month, as a result of having smoked cigarettes

Number of U.S. residents who would die of anthrax in the coming year if the October 2001 rate (when anthrax became the top news story) continued 48

Number of children in Afghanistan that the United Nations estimates may die this winter from pneumonia and diarrhea

100,000

Probability that someone who flies once a month will die in a commercial airplane crash in the coming year in the United States (where concern about terrorism has cut flying sharply), if terrorists hijack and crash one plane every month 1 in 540,000

Probability of dying of a heart attack in the United States (where tens of millions of people fail to exercise or maintain healthy diets despite the risk), in the same year

1 in 400

Odds of a U.S. resident being killed by terrorists in a shopping mall, in the coming year, if the person spends two hours a week in malls and if terrorists destroy one mall (and everyone in it) each week

1 in $1,500,000$

Odds of the average U.S. resident being killed in that year by cancer

1 in 600

${ }^{9}$ Reprinted with permission of World Watch Magazine, Vol. 15, No. 1, copyright 2002, www.worldwatch.org
These examples illustrate that human society's response to risk is based more on emotion than evidence. The dangers of some risks are even being denied. The global risks from a major environmental disequilibrium would make these large numbers seem modest. Responses are not compatible with probable causes of harm, and the dangers of living unsustainably have not received the attention they deserve.

In the US, the 'baby boomer generation' (those in the age range of late thirties to mid-fifties) is concerned about retirement years and whether the Social Security and health care systems will continue to work as well as they did for previous generations. Most of the baby boomer generation believe these systems will not continue. Even though retirement and health care are great concerns, a greater concern exists: will the planet be as habitable for future generations? Health care for the planet's ecological life support system must be considered. Environmentally literate persons know of many reasons for concern. The ecological space available per capita on the planet has decreased from between 5-6 hectares to 1.5 hectares in the twentieth century (Wackernagel \& Rees 1996). Natural capital, such as forests (e.g. Brown 2001), wetlands (National Research Council 1992), and fossil water (i.e. underground aquifers), are diminishing (Postel 1999) at rates far greater than replacement. In addition, the world sunshine has diminished $10 \%$ to $37 \%$ (Chang 2004); dead zones occur in marine ecosystems ${ }^{10}$; and the effects of the oil spill in Prince William Sound are still evident after 15 years. ${ }^{11}$ These few examples illustrate the worsening environmental conditions.

Cultural changes are also important factors. In 1999, American gangs in the school systems were composed of these cultural proportions: white, non-Hispanic, $12 \%$; black, non-Hispanic, $25 \%$; Hispanic, $28 \% .{ }^{12}$ Arguably, major climate changes would produce both severe social and environmental stress. If the ice covering Greenland were to melt or slide into the sea, the oceans of the planet would rise. Barranger ${ }^{13}$ describes a situation in the US national parks, particularly the

\footnotetext{
${ }^{10}$ See 'Dead zones increasing in world's coastal waters,' 16 June 2004, from Earth Policy Institute, available from Environmental News Network online at www.enn.com/direct/displayrelease. asp? objid=D1D1366D000000FD2E251DE38084ED4A

${ }^{11}$ See '15 years later, Exxon Valdez oil spill lingers', by JR Pegg, from People and the Planet, 7 April 2004, available online at www.peopleandplanet.net/doc.php?id=2189

${ }^{12}$ See 'Indicators of school crime and safety', from the US Department of Education and US Department of Justice (Bureau of Justice Statistics), Oct 2000, Table 16-3. Available online at http://nces.ed.gov/pubs2001/2001017.pdf

${ }^{13}$ See 'Critics say clean air plan may be a setback for the parks,' by F Barranger, 31 May 2004, available online at http://home.earthlink.net/ cevent/5-31-04_clean_air_setback_for_parks.html
} 
Great Smokey National Park, in which a proposed federal 'clean-air' plan would actually reduce visibility to an unacceptable level.

\section{SPECIAL INTERESTS}

The global environmental crisis, when considered at all, is almost always peripheral to the focus on individual and organizational special interests. Orr (2004) has persuasively argued that partisan wrangling is a symptom of a deeper dysfunction. Humans may not be denying so much the global environmental malaise (extinction, habitat destruction, ecosystem fragmentation, etc.), but rather they may be focusing so intently on their special interests that the larger events, which will markedly affect both any special interests and the quality of life, get little or no attention. For example, projections are that the current global population of over 6 billion humans might reach 9 billion in 50 years or less. Ninety percent of this growth is projected for developing nations. Even those aware of this situation are reluctant to limit population size to the planet's carrying capacity because such a limit would be tramping on 'individual rights', and sovereign nations (even those now dependent on imported food) would almost certainly not comply. However, very few people would hesitate to object if an elevator were occupied by more people than its carrying capacity. Is this because individual interests are likely to be immediately adversely affected, or because of the hope of making a difference, or both?

Humankind definitely wishes to escape vulnerability, whether from terrorists, aging, or intimate relationships. Denial of vulnerability does not erase the susceptibility. In the context of sustainable use of the planet, humankind is denying that it cannot transcend the iron laws of nature and the universe; this denial is a severe handicap. Indeed, the most striking example of this denial is the continued assertion that infinite growth on a finite planet not only is possible but also is desirable. Bartlett \& Lytwak (1999) have noted that population momentum is either ignored or denied. If the 'normal' US life span of 70 years is considered, then lowering the fertility rate to 2.1 children per woman (replacement rate) would result in a gradual drop in population growth rate. However, the rate would not reach zero for 70 years, and, during this interval, the population would continue to grow.

Sustainability requires a willingness to accept the uncertainties of natural systems and to be exposed to natural law - after all, humankind is a component of the interdependent web of life rather than the centerpiece. In this view, humankind is more like the millions of other species (both plant and animal) on the planet, which means that much is beyond human control. Some natural events may severely disrupt or even end human lives. Humankind's denial of its dependence on the planet's ecological life support system and its vulnerability to the laws of nature is part of a larger pattern of denial.

Humankind is denying survival to a large array of species and leaving a less habitable planet for future generations when it damages planetary ecosystems. If humankind continues to act as it is presently, it is denying responsibility for actions that will have far reaching consequences.

Davidsen \& Rees-Mogg (1997) predict the demise of the nation-state, primarily due to the rapid development of cyberspace. Local centers of power will reassert themselves as the state develops into fragmented overlapping sovereignties (e.g. Tilly 1993). ${ }^{14}$ If the nation-states are indeed in decline, this event is very important since most nation-states espouse exponential economic growth, deny the reality of carrying capacity, and have routinely subsidized environmentally damaging activities (e.g. Myers with Kent 1998). Eliminating perverse subsidies is an obvious, major step toward achieving sustainable use of the planet. Myers with Kent (1998) estimate that subsidies of approximately US\$1.5 trillion are larger than the economies of all but five countries in the world. Present and future generations are and will be markedly affected if these perverse subsidies continue.

\section{DENIAL VERSUS IRRATIONAL EXUBERANCE}

Most persons in 'developed countries', who are the largest consumers of planetary resources, also believe that human creativity, technology, and economic growth will solve all problems and continuously improve the human condition. The exponential growth and vastly increased affluence of many humans seem to support this assumption because, in the short term, they appear to indicate no limits to growth for Homo sapiens. This situation is particularly true in the 200+ years since Malthus (1798) published his still controversial book on population growth. However, exponential growth and increased affluence seems to be the result of unsustainable practices that may destabilize human society in the 21st century. At present, over half of the world's population is living in conditions that are far from enviable; global climate change,

\footnotetext{
${ }^{14} \mathrm{~A}$ detailed examination of these issues is available in a special issue of Global Environmental Politics, Vol. 4, No. 1, February 2004, edited by F Biermann and K Dingwerth. Interesting evaluations of these issues may also be found in Dalby (2004), Conca (2004), and Lipschutz (2004)
} 
including changes in the hydrological cycle, could easily and rapidly worsen existing conditions. ${ }^{15}$ Many environmental and ecological functions are non-linear; since doubling times (e.g. population, some types of climate change, and resource consumption) are nonlinear as well, critical breakpoints and thresholds can be reached in far less time than expected by those who assume these activities are linear functions.

In general, social systems are slow to respond to environmental crises, especially when they involve large temporal and spatial spans. If decision makers and the general public must witness evidence of damage to human health and the environment before taking remedial action, the measures will be both less effective and more costly. However, taking precautionary action (while significant uncertainty still exists about the circumstances that will probably result in damage) requires a much higher level of environmental literacy than the level of most current decision makers and the general public.

A major, unanswered question concerns the degree that unmistakable damage to human health and the environment in one geographic area will influence decisions on similar problems in other geographic areas. Cultural differences, level of affluence, etc. will also probably affect the influence of case histories in other parts of the world. Clearly, sustainable use of the planet will require precautionary measures to avoid problems, not remedial action after the damage has occurred. Denial of the probable existence of problems until damage occurs is an ineffective way to resolve sustainability issues, especially when many more resources are required to repair environmental damage than to prevent it. The planet's biospheric life support system should have the highest priority for protection, maintenance, and repair since it is by far the most important factor in the quest for sustainable use of the planet. Both the future of humankind and the human economic system depend on its integrity and well-being. Humankind once acknowledged the necessity of a healthy biospheric life support system, but the technological and economic successes of the last few centuries, insignificant in geological time, have led to the belief that humans now transcend natural law. The evidence of this belief can be found throughout the globe, but humankind has become addicted to unsustainable practices that lead to an unhealthy biospheric life support system. Many of humankind's unsustainable practices are simple to state.

\footnotetext{
${ }^{15}$ See 'Heavy debt and drought drive India's farmers to desperation', by A Waldman. From the New York Times, 6 June 2004, available online at www.nytimes.com/2004/06/06/ international/asia/06INDI.html?th
}

1. Denial that humankind inhabits a finite planet with limited resources and a finite carrying capacity for humans.

2. Denial of limits to growth, which enables humankind, for a short time at least, to continue present practices.

3. Denial that a human being is part of a whole called by many cultures 'the universe'. Humankind is part of an evolutionary system with participation possibly limited in time and space ${ }^{16}$, even though individuals may perceive themselves as an entity separated from the interdependent web of life. This perception is a delusion. Sustainability requires that humankind free itself from this delusion by expanding its compassion from 'targeted' to 'generalized', embracing natural systems as well as future generations of its species with whom it shares planet Earth (Cairns 1998). Of course, this goal will remain, for the near future, an aspiration for both individuals and society, but it is essential to achieving sustainable use of the planet.

4. Denial that humankind is both a victim and a beneficiary of its cultural conditioning. Technologies (e.g. agricultural and industrial) have enabled humankind to modify some of nature's laws and adapt some habitats that were marginally habitable to make them moderately habitable. Domestication of a few species of plants and animals has resulted in additional security in food supply. As a consequence, awe of nature has been replaced by a feeling of dominance and control. However, nature still intrudes upon human lives (e.g. weather, disease, invasive species), so human society is not divorced from nature. Humankind has the power to improve the relationship between itself and natural systems. The current computer era and humankind's language-based cultural system provide an unprecedented opportunity to develop a mutualistic relationship with natural systems. However, at present, no persuasive evidence indicates that either of these tools will be used toward this end.

5. Denial that humankind has denigrated the value of the covenant with the natural systems on which humans are dependent for their survival. The covenant was established, confirmed, and reconfirmed by certain rites involving sacred tokens from the organisms themselves, a symbol that, when animals were slain or plants were consumed, their components should be returned to the mother source for rebirth (Eldridge 1991). As Eldridge (1991) notes, when such rites were performed and the mystery of the order of nature thus recognized, it was hoped that the food supply of the human community would be assured.

\footnotetext{
${ }^{16}$ See 'Future of life on Earth', by John Cairns, Jr. ESEP 2004:1-2. Available online at www.esep.de/articles/esep/ 2004/E41.pdf
} 
6. Failure to refute the distortions of scientific evidence by op-ed commentaries attacking the conclusions of mainstream science by those with far less impressive academic credentials (e.g. London 2002). As Cairns ${ }^{17}$ remarks, life on Earth will endure - what needs to be saved are the conditions that support human life. In the long term, natural law will eradicate species that place natural systems in disequilibrium and impair their capacity for self-maintenance. Some people concerned about environmental problems are labeled 'environmental doomsayers' (e.g. London 2002). The people who use this label for environmentalists blithely ignore the fact that many more ways of living exist than the ones now used, no matter what they are (Quinn 1999). The people whom London (2002) labels 'environmental doomsayers' are concerned about humankind's future; they are not interested in preserving the status quo but only those components that are both sustainable and ethical.

7. Failure to remedy the maldistribution of resources. Nature gives up resources grudgingly; however, they are distributed fairly equitably among more than 30 million species. With finite resources on a finite planet, distribution among this huge number is no small achievement. This feat is accomplished by resource partitioning - each species has a competitive edge for a relatively small component of the total resources available. Species that exceed resource carrying capacity suffer famine and disease, which make many of them more vulnerable to predation. Some species exhibit strong territoriality. The waste products of one species may serve as resources for other species. Tribalism is the result of natural selection and has worked well for humans and other species. All members of a tribe or other biological, social community are involved in the success of the tribe. There is little compassion for misfits. Natural systems are characterized by substantial loss of individual lives.

Smail $(2002 \mathrm{a}, \mathrm{b})$ has remarked upon the increasing tension between two, seemingly irreconcilable trends: (a) projections indicate that human population trends will reach or exceed 9 billion by the mid-to-late twenty-first century and (b) increasingly reliable scientific estimates indicate that Earth's long-term, sustainable carrying capacity may have already been exceeded (Wackernagel et al. 2002). To continue to deny that this dichotomy exists defies common sense. This statement is not 'gloom and doom', but rather a proposal acknowledging that humankind has an obligation to develop a harmonious and mutualistic relationship between humankind and natural systems that is sustainable. Goals and conditions must be provided to make the vision a reality (e.g. Cairns 1997). A belief

\footnotetext{
${ }^{17}$ See Footnote 16
}

that civilization as now practiced is unsurpassable is foolish, arguably fatal. One area that could be dramatically improved is eco-ethics, which should be the unifying theme of the vision. Making the planet more habitable for humankind and other species is the sine qua non of eco-ethics.

8. Failure to redefine civilization or to develop a new word to describe the vision of sustainable use of the planet. The word civilization is homocentric, and sustainability requires an ecocentric word. Homo sapiens has 'overrun' Earth and 'subjugated' nature. This result was perceived as inevitable, even ordained. Furthermore, substantial benefits have accrued to those who accept civilization as it is defined at present. Individuals who improve life for humankind are rewarded with power, wealth, and respect. However, the benefits that a few humans acquire are not widely distributed among humankind. At least $30 \%$ of the 6 billion people on the planet are poorly or marginally fed and housed. Consequently, a paradigm shift to a mutualistic relationship is at least possible since, for many, human society seems out of control. A number of scenarios could play out in this continuing, unsustainable relationship, from devastating effects upon humankind to moderately severe effects (Cairns 2000-2001).

\section{TRANSCENDING DENIAL}

Denial does not protect either individuals or societies. At best, denial temporarily postpones facing issues that persist until they are resolved with reason aided by intelligence. Denial can be lethal or, at best, damaging. Worse yet, denial can adversely affect both present and future generations. Even the best value system cannot stop the inevitable death of the planet, but a sustainable value system will enable humankind to persist much longer than denial will. Denial of reality (in this case, of the rule of natural law) can be fatal to both individuals and cultures.

Ehrlich (2000) gives a comprehensive overview of humankind's biological and cultural evolution. He discusses not only the processes that produced Homo sapiens but also the many facets of evolution that will markedly affect humankind's future. Humans began as a small tribal species that was spread thinly over the planet with only primitive technology to extract resources from natural systems. Connections with natural systems were intimate, and severe penalties arose from inappropriate actions. Now the human population exceeds 6 billion and is still growing globally. Furthermore, massive technology allows extraction of resources from natural systems at a much greater rate. Expectations of material consumption are high and growing. To deny that these factors have not produced 
major problems will worsen the rapidly deteriorating environmental circumstances and will improve neither cultural evolution nor humankind's relationships with natural systems.

Before civilization as defined at present, each individual had to have a realistic view of the area of the planet s/he inhabited. Realistic survival techniques included avoiding predators, hunting and gathering food, selecting shelter, and ensuring adequate water. Modern Homo sapiens successfully persisted on Earth for 120000 years before the agricultural revolution. Hunters/gatherers may have spent as little as $20 \%$ of their time securing adequate nourishment (2000 calories per day), at a cost of 400 calories.

\section{DENIAL, MEMES, AND SILENCES}

In The Selfish Gene, Dawkins (1990) states that memes (the replicating cultural units of transmission) are to cultures what genes are to bodies. ${ }^{18}$ Memes can be both helpful and lethal to cultures. Especially dangerous are globally accepted beliefs such as the belief in perpetual economic growth or the belief that human technology and creativity free humankind from natural law. One important natural law is that a carrying capacity exists for each species that cannot be exceeded for long periods of time. When a lethal meme is widely accepted, catastrophe on a global scale becomes highly probable. Memes enable denial to continue despite substantial evidence to the contrary. For example, the US is resisting, arguably blocking, attempts to reduce greenhouse gases because of presumed adverse effects on the economy. Yet, global warming could destabilize civilization as known at present. Fortunately, some world leaders (e.g. UN Secretary General Kofi Annan [Annan 2002]) explicitly list the most important, potentially devastating environmental challenges, as well as a vision of green technologies, livable cities, and rising quality of life for a majority of humankind rather than just a fortunate minority. Most people accept the present situation both because they hope to be a part of the fortunate minority and because they have been acquiring more every year for decades (at least more of a few things - more food for less money, more clothes, and the perception of more tax relief). However, with resources becoming scarcer and the human population still growing, the prospects for joining the wealthy elite grow smaller every year. Further, the wealthy power elite has found that tranquility and happiness have generally remained elusive, although it appears to remain per-

\footnotetext{
${ }^{18}$ Ehrlich (2000) has a superb and well-referenced book on both cultural and genetic evolution in humans
}

suaded that more power and more wealth will correct this situation.

Ehrlich (2000) is not enamored with the meme hypothesis of cultural evolution, but does note that quantitative approaches to cultural evolution (e.g. Cavalli-Sforza \& Feldman 1981) have been scientifically profitable. Ehrlich (2000) does believe that cultural and other environmental variations play a role in the evolution of humankind, compared to genetic evolution.

Nicholson (2002) believes that humans are reluctant to speak about important issues because openness makes them vulnerable and, thus, removes them from the 'enclosure' of privacy. Denial is probably not the word to use in this situation - Nicholson uses the word silence.

Orr (2004) believes that the whole political machinery that connects the values and ideals of American citizens with public policy has been severely damaged, possibly broken. Orr presents an unsettling evaluation of the environmental consequences humans will face unless citizens develop the political will to reverse current trends. He states that patriotism, heightened by fears of terrorism, is a major factor in this dysfunctional system and will adversely affect posterity. Despite Orr's disquieting analysis, he has both a positive view of the future of the human species and a plan for leaving a habitable planet for future generations. True patriotism may have severe penalties. For example, Thompson reports that a federal biologist and the team's advice were illegally ignored before a major fish kill in 2002 on the Klamath River. ${ }^{19}$ The federal government was politicizing scientific decision making and misleading the public. Pegg reported another instance in which an attempt was made to time the release of information on the closure of an Oceans Commission report to occur before the US national elections. $^{20}$

Another possibility is that, in some instances, uncertainty may appear to be denial. For example, some professionals have predicted an oil shortage (e.g. Editorial 2003, Goodstein 2004) and that the petroleum age is far from over (e.g. Maugeri 2004). Malakoff (2004) examines the possibility that some at-risk species (e.g. bluefin tuna and blue whales) appear to congregate along oceanic 'fronts' where cold and warm water masses meet. These fronts may exist for relatively long periods of time and may even result in areas rich in

\footnotetext{
${ }^{19}$ See 'Federal whistleblower quits, alleges politicization of science', by D Thompson, 19 May 2004. Available online at www.sfgate.com/cgi-bin/article.cgi?file=/news/archive/ 2004/05/19/state1745EDT0118.DTL

${ }^{20}$ See 'Oceans Commission chair urges closure before election day', by JR Pegg, 25 May 2004. Available online at http://shiftingbaselines.org/blog/archives/000125.html
} 
fisheries. However, much must still be learned about these areas. One thing is clear - this level of scientific uncertainty requires a high level of scientific literacy and may be ignored (not denied) because of both complexity and uncertainty. The same is true of such complex issues as the deterioration of world food security. ${ }^{21}$

In the US, alarm has increased over the number of overweight people (McGraw 2003). Is the silence in the US on an imminent food crisis due to denial, guilt, or a lack of awareness of the problem? A related issue (noted in Quigg 2004) is whether drought in the American West is a cyclic problem or a new trend.

In addition, ambivalence exists about repairing some of the ecological damage that humankind has done. Willott reported on a case in Tucson, Arizona, USA, of current riverbeds that are often dry; however, in the 1800 s, they were often filled with water, but also malaria. ${ }^{22}$ At present, malaria does not exist in the Tucson basin, but the West Nile virus does. The benefits of wetland restoration are numerous (e.g. National Research Council 1992), including ecosystem services such as water purification, removal of sediments, flood reduction, and use as major wildlife habitats. However, Willott noted that repair of nature in one area may mean an alteration in the social context. ${ }^{23}$ To achieve sustainable use of the planet, humankind can neither assume an either/or attitude nor remain silent on the issues.

\section{IDEALIZATION VERSUS REALITY}

If humankind achieves sustainable use of the planet (or a close approximation thereof), it will be because billions of people share a new vision and use it to guide their practices. These billions can be amassed because thousands and/or millions who are living more sustainably should inspire other individuals. Individuals who live a life that is materially frugal, in harmony with nature, and yet have had an enriching, quality experience have caused many people to reexamine their lifestyle, including the satisfaction of developing a more harmonious relationship with natural systems (e.g. Wirzba 2003).

As a citizen of the US, which has the largest ecological footprint of all nations, I felt a personal responsibil-

\footnotetext{
${ }^{21}$ See 'World food security deteriorating: food crunch is 2005 now likely', by LR Brown, 2004. From the Earth Policy Institute, available online at www.earth-policy.org/Updates/ Update $40 . \mathrm{htm}$

${ }^{22} \mathrm{See}$ 'Can we restore wetlands and leave the mosquitoes out?', by K Rogers, 25 May 2004. Available online at http://uanews.org/cgi-bin/WebObjects/UANews.woa/4/ wa/SRStoryDetails?ArticleID $=9253$

${ }^{23}$ See Footnote 22
}

ity to see how much of my personal footprint size could be reduced. Wackernagel \& Rees (1996) provide a discussion of how the ecological footprint size is calculated. There are numerous Internet sites for determining personal ecological footprint size. ${ }^{24}$ Figure 1 in Rees and Wistra (2003) graphically illustrates equitable (i.e. population-based) versus actual appropriation of global carrying capacity by selected countries. The US, with less than $5 \%$ of the global population, appropriates about $24 \%$ of global carrying capacity. Much can be done in the US to reduce footprint size. Residents of wealthy nations average 5-10 hectares/capita while residents of China require only 1.2 hectares (Wackernagel et al. 1999). If individuals realized that lifestyle changes could be incremental, they would be less likely to indulge in denial. Denial occurs most often if an entire lifestyle appears threatened. Furthermore, a modest change in a single component of a lifestyle (e.g. energy consumption) is likely to result in a significant improvement in sustainability. Denial appears more likely if individuals are told they will have to give up everything if they embrace sustainable use of the planet-'back to the Stone Age' is a transparent but effective tactic for oppositionists. The quality of life appears threatened when, in fact, excessive consumption is the target. An obligation of giving up cars is more threatening than an appeal to use the car less. However, if a substantial number of people used cars less, greenhouse gases would diminish. Living comfortably without a car in most small US towns is difficult, but not impossible. However, if small towns had been designed with more neighborhood stores within walking distance, dependence on automobiles would be reduced and social capital would increase. Americans now drive to exercise facilities when walking to the local store would benefit both the individual and the environment.

On a finite planet with limited resources and a growing demand on them, a simpler, less materialistic lifestyle is inevitable. Exponential growth alone will ensure simplicity and less materialism. This crisis could come earlier than expected due to water shortages, climate change, terrorism, ethnic conflict, etc., which will worsen already troublesome conditions. Humankind is blessed with a sophisticated intellect, but denial of evidence that Earth's ecological life support system is being degraded at a rate unprecedented in human history results in stupid decisions that are harmful to both individuals and humankind. Dawkins (1990) asserts that individuals are temporary housing for genes from generation to generation. Presumably, human intelligence will have sur-

\footnotetext{
${ }^{24}$ See, for example, 'Calculate your ecological footprint,' at http://www.myfootprint.org
} 
vival value when the environmental crisis intensifies, even if it does not seem to function effectively in eliciting precautionary measures that would lessen or avoid the crisis. Memes, both lethal and benign, are transmitted from mind to mind through cultures. Consequently, changing individual minds affects the survival value of memes. As a consequence, denial might be overcome rather rapidly. The future of humankind may depend on the validity of this hypothesis.

However, Dobson (2003) reluctantly concludes that social justice and environmental sustainability are not always compatible objectives. Rees and Wistra (2003) pose an equally challenging issue that must also be addressed before the loss of ecological resiliency occurs. Denial of serious sustainability issues is not prudent. Abernethy (e.g. 1994) has shown that motivation, rather than differential access to contraceptive methods and information, is the primary determinant of fertility. ${ }^{25}$ Individuals respond to scarcity by having fewer children and to a perceived better future by having more children. In short, successful economic development does not reduce family size but, where perceived economic opportunity is good, family size increases.

The few selections from relatively recent publications that follow provide food for thought on the question of denial.

(1) The world's most populous country, China, has a significantly shrinking grain harvest, as do many other countries with large populations. ${ }^{26}$

(2) Oxygen deficient areas of the world's ocean, 'dead-zones', that are devoid of fish are spreading. The number has doubled since $1990-150$ zones have been identified globally. Some are as large as 27,000 square miles. ${ }^{27}$

(3) It was once believed that hatchery salmon could help maintain wild populations but there is persuasive evidence that this is an unjustified expectation. ${ }^{28}$

(4) The Los Angeles Times notes that carbon dioxide levels have reached record high levels after growing at

${ }^{25}$ See also Abernethy VD (2002) Fertility decline; no mystery. ESEP 2002:1-11, available online at www.esep.de/articles/esep/2002/article1.pdf

${ }^{26}$ See 'China's shrinking grain harvest' by LR Brown (2004). From the Earth Policy Institute, available online at www.earth-policy.org/Updates/Update36.htm

${ }^{27} \mathrm{See}$ 'UN warns about ocean 'dead zones', by H Greimel, 29 March 2004, available online at www.3reef.com/cgibin/yabb/YaBB.pl?board=Evironmental;action=display;num $=1080578142$

${ }^{28}$ See 'Hatchery salmon cannot replace disappearing wild fish', by JR Pegg. From the Environmental News Service, 26 March 2004, available online at www.flmnh.ufl.edu/fish/ InNews/replace2004.html an accelerated pace last year. ${ }^{29}$ This important greenhouse gas is a major factor in climate change.

(5) The human economy may well have overshot Earth's carrying capacity by exceeding its regenerative capacity (Wackernagel et al. 2002)

Many other examples of denial can be found in publications of the United Nations, The Earth Policy Organization, and Worldwatch. An important factor is accusations that US President Bush's administration has systematically distorted scientific fact and stacked technical advisory committees to advance favored policies on the environment (Glanz 2004). Dr. Charles M. Vest, president of the Massachusetts Institute of Technology, has cautioned against a very long-term trend toward selective use of scientific information driven by political and ideological motivations. Arguably, this trend is the most pernicious form of denial.

In the quest for sustainable use of the planet, humankind may be nearing a point of 'no return' (i.e. irreversible damage to the biospheric life support system). The closer this point is approached, the more difficult management becomes. Considerable uncertainty exists about the precise breakpoint of the biospheric system, but, clearly, much damage is being done to it. Denial that the problem exists will only result in being spectators to a tragedy that could have been avoided. As McNeill (2000) has documented, the rate of environmental deterioration seems to be accelerating. The cult of hyperindividualism (i.e. focusing on the individual condition) appears to be accompanied by a belief that individual interests are divorced from the interests of humankind, including posterity. For example, mainstream science has been aware of the threat of global warming for more than a decade, but both nationstates and individuals all too often refuse to change their behavior to prevent exacerbating the problem. Sustainability is larger than the individual, and humankind cannot deny that an ethical behavior is required to transcend the individual. Still, the recognition of the need for ethical behavior could grow into a major political force globally. Regrettably, history indicates that major crises need to become painfully obvious before a paradigm shift occurs.

Why do people remain unconvinced and unconcerned despite increasing evidence that humankind is seriously reducing the chances of achieving sustainable use of the planet (Ehrlich \& Ehrlich 2004)? Ehrlich \& Ehrlich note that Americans, although major contributors to resource consumption and anthropogenic greenhouse gases, seem mostly oblivious to the poten-

\footnotetext{
${ }^{29}$ See 'Carbon dioxide levels rising faster; buildup sets record', 21 March 2004, available online at www.latimes.com/services/ site/premium/access-registered.intercept (access limited to registered users)
} 
tially massive threats caused by excessive resource consumption (i.e. beyond regeneration or replacement capacity) and increasing pollution of the environment.

Acknowledgements. I am indebted to E Call for transcribing the handwritten draft and to D Donald for both editorial assistance and retyping several drafts of this manuscript. A Heath furnished useful comments on the second draft. P Kullberg, P Ehrlich, J Tanton, and E Rubenstein called useful articles to my attention.

\section{LITERATURE CITED}

Biermann F, Dingwerth K (2004) Global Environmental Politics. Guest editors, special issue. February 4(1)

Abernethy VD (1994) Optimism and overpopulation. Atlantic Mo 84-91

Annan K (2002) Beyond the horizon: will the future be barren or bountiful? Time 160(9):A18-19

Bartlett AA, Lytwak EP (1999) The arithmetic of population momentum. In: The biocentric imperative. Social Contract Press, Petosky, MI, p 21-25

Browder J, Cairns J Jr, Grady J, Miller O, Robinson-Beers K, Skabelund L (2000) Brown farm decisions call for visionary readership. Roanoke Times 29 Oct: NRV2

Brown LR (2001) Eco-economy. WW Norton, New York

Brown LR (2003) Plan B: Rescuing a planet under stress and a civilization in trouble. WW Norton, New York

Cairns J Jr (1997) Commentary: defining goals and conditions for a sustainable world. Environ Health Persp 105(11): $1164-1170$

Cairns J Jr (1998) Replacing targeted compassion with multidimensional compassion: an essential paradigm shift to achieve sustainability. Spec Sci Tech 21:45-51

Cairns J Jr (2000-2001) Speculative scenarios: Is there a way to use and sustain our planet? TSC Journal 11(2):146-152

Carson R (1962) Silent spring. Houghton Mifflin, Boston

Cavalli-Sforza LL, Feldman MW (1981) Cultural transmission and evolution: a quantitative approach. Princeton University Press, Princeton

Chang K (2004) Globe grows darker as sunshine diminishes $10 \%$ to $37 \%$. New York Times, 13 May late edn-final: A22

Conca K (2004) Ecology in an age of empire: a reply to (an extension of) Dalby's imperial thesis. Global Environ Pol $4(2): 12-19$

Dalby S (2004) Ecological politics, violence and the theme of empire. Global Environ Pol 4(2):1-11

Daly HE (2003) Ultimate confusion: the economics of Julian Simon. TSC Journal 13(3):194-197

Davidsen JD, Rees-Mogg W (1997) The sovereign individual: how to survive and thrive during the collapse of the welfare state. Simon \& Schuster, New York

Dawkins R (1990) The selfish gene. Oxford University Press, Oxford

Dobson A (2003) Social justice and environmental sustainability: ne'er the twain shall meet? In: Agyeman J, Bullard RD, Evans B (eds) Just sustainabilities. MIT Press, Cambridge, p 83-95

Dobzhansky T (1945) Review of 'Evolution, creation, and science' by Frank Lewis March. Am Nat 79:73-75

Editorial (1997) Science vs antiscience? Sci Am 276(1):96-97

Editorial (2003) The end of the oil age. Economist 11:61-63

Ehrlich PR (2000) Human natures: genes, cultures, and the human prospect. Island Press, Washington, DC

Ehrlich PR, Ehrlich AH (2004) One with Nineveh: politics, consumption, and the human future. Island Press, Washington, DC

Eldridge N (1991) The miner's canary: unraveling the mysteries of extinction. Princeton University Press, Princeton

Glanz J (2004) At the center of the storm over Bush and science. New York Times, 30 March, last edn-final: F1

Goodstein D (2004) Out of gas: the end of the age of oil. WW Norton, New York

Hardin G (1968) The tragedy of the commons. Science 162 $1243-1248$

Hardin G (1972) Living on a lifeboat. BioScience 24:561-568

Hardin G (1974) Exploring new ethics for survival: the voyage of the Spaceship Beagle. Viking Press, New York

Hardin G (1976) Carrying capacity as an ethical concept Soundings 59:120-137

Hardin G (1999) The ostrich factor. Oxford University Press Oxford

Kuhn TS (1970) The structure of scientific revolutions, 2nd edn. University Press of Chicago, Chicago

Leopold A (1949) Sand county almanac. Oxford University Press, New York

Lipschutz RD (2004) Imitations of empire. Global Environ Pol $4(2): 20-23$

Lomborg B (2001) The skeptical environmentalist: measuring the real state of the world. Cambridge University Press, Cambridge

London H (2002) Don't believe in environmental doomsayers. Roanoke Times, 25 Aug: Horizon 3

Malakoff D (2004) New tools reveal treasures at ocean hot spots. Science 304:1104-1105

Malthus TR (1798) Population: the first essay. Reprint, University of Michigan Press, Ann Arbor, MI

Maugeri L (2004) Oil: never cry wolf - why the petroleum age is far from over. Science 304:1114-1115

McGraw PC (2003) The ultimate weight problem: the 7 keys to weight loss freedom. Simon \& Schuster, New York

McNeill JR (2000) Something new under the sun: an environmental history of the twentieth-century world. WW Norton, London

Myers N with Kent J (1998) Perverse subsidies: tax \$s undercutting our economies and environment alike. International Institute for Sustainable Development, Winnipeg Manitoba

National Research Council (1992) Restoring aquatic ecosystems. National Academy Press, Washington, DC

Nicholson SW (2002) The love of nature and the end of the world: the unspoken dimensions of environmental concern. MIT Press, Cambridge

Odum HT, Odum EC (2001) A prosperous way down. University Press of Colorado, Boulder, CO

Orr DW (2004) The last refuge: patriotism, politics, and the environment in an age of terror. Island Press, Washington, DC

Palmer M, Bernhardt E, Chornesky E, Collins S, and 17 others (2004) Ecology for a crowded planet. Science 304: $1251-1252$

Postel S (1999) Pillars of sand. WW Norton, New York

Quigg A (2004) The arid West. New York Times, 10 May natl edn: A24

Quinn D (1999) Beyond civilization: humanity's next great adventure. Three Rivers Press, New York

Rees WE, Wistra L (2003) When consumption does violence: Can there be sustainability and environmental justice in a resource-limited world? In: Agyeman J, Bullard RD, Evans B (eds) Just sustainabilities. MIT Press, Cambridge, p 99-124 
Sheehan H (1993) Marxism and the philosophy of science: a critical history. Humanities Press International, Atlantic Highlands, NJ

Simon J (1981) The ultimate resource. Princeton University Press, Princeton

Smail JK (2002a) Remembering Malthus: a preliminary argument for a significant reduction in global human numbers. Am J Phys Anthropol 118:292-297

Smail JK (2002b) Confronting a surfeit of people: reducing global human numbers to sustainable levels. Environ Dev Sustain 4:21-50

Tilly C (1993) Coercion, capital, and European states AD 1990-1992. Blackford, Oxford, UK

Tromp TK, Shia R-L, Allen M, Eller JM, Yung YL (2003)

Editorial responsibility: Professor Sam Berry (Editor),

London, UK
Potential environmental impact of a hydrogen economy on the stratosphere. Science 300:1740-1741

Wackernagel MW, Rees WE (1996) Our ecological footprint: reducing human impact on Earth. New Society Publishers, Gabriola Island, BC, Canada

Wackernagel M, Onistro L, Bello P, Linares A, Falfan I, Garcia I, Guerrero A, Guerrero M (1999) National natural accounting with ecological footprint concept. Ecol Econ 29:375-390

Wackernagel M, Schulz NB, Deumling D, Linares AC, and 7 others (2002) Tracking the ecological overshoot of the human economy. Proc Nat Acad Sci 99(14):9266-9271

Wirzba N (ed) (2003) The essential agrarian reader. University Press of Kentucky, Lexington, KY

Submitted: April 16, 2004; Accepted: June 15, 2004

Proofs received from author(s): July 27, 2004

Published on the web: July 29, 2004 